\title{
CLUSTERS OF MINERAL DEPOSITS OF THE SOUTHERN EAST SIBERIA AND PROSPECTS FOR THEIR DEVELOPMENT: AN OVERVIEW OF THE PROBLEM
}

\author{
Zh.V. Seminskiy ${ }^{\otimes}$
}

Irkutsk National Research Technical University, 83 Lermontov St, Irkutsk 664074, Russia

\begin{abstract}
This study aims to identify the groups of closely spaced mineral deposits located in the Southern East Siberia and to describe these clusters. The mineral resource base of this region includes the deposits of lead, zinc, tungsten, tin, molybdenum, uranium, copper, gold, lithium, tantalum, niobium, silver, fluorite, zirconium, rare-earth metals, iron, mica, precious and semi-precious stones, oil, gas, and coal. Many of these deposits contain a significant part of the explored mineral reserves of Russia. The deposits are located in the tectonic structures of the Siberian platform (Tunguska syncline, Nepa arch, Cheremkhovo and Priangarie depressions), as well as in the fold belts framing the platform from the south and southeast (Baikal-Patom, Dzhida-Vitim, etc.). These structures and belts formed under the influence of plate tectonic and plume tectonic processes. This article describes the clusters of mineral deposits of the Angara, Sayan, Baikal and Transbaikalia regions. Currently, the most developed are the clusters located in the southern part of the study area (Shilka, Argun, Yeravnino, etc.). In the northern part (Mama-Bodaibo, etc.), the clusters have been either partially developed within the existing mining areas or are at the initial stage of development. In these territories, the road infrastructure, power supply and other facilities required for mining industry are either underdeveloped or lacking. Prospects for the regional development are related to the economic development of the territories adjacent to the Baikal-Amur railroad (BAM) and hydrocarbons production in the zone near the East Siberia - Far East oil pipeline. On the Siberian platform, mineral deposits formed during the stages of formation of its basement (Aldan, Anabar, and Sharyzhalgai shields) and platform cover (Tunguska syncline, and Nepa-Botuoba anticline). Within the fold frame, ore formation was associated with subduction, spreading, collision, and plume tectonic intraplate settings. To start the development of small-size deposits and mining of technogenic raw materials, it is advisable to establish exploration and production enterprises that can operate and manage expeditions and use compact ore-dressing plants.
\end{abstract}

KEYWORDS: mineral deposits; geodynamic settings; clusters of mineral deposits; mineral raw materials; development prospects; East Siberia

\section{REVIEW}

Correspondence: Zhan V. Seminskiy, zhsemizur@yandex.ru
Received: May 13, 2021

Revised: June 29, 2021

Accepted: July 12, 2021

FOR CITATION: Seminskiy Zh.V., 2021. Clusters of mineral deposits of the Southern East Siberia and prospects for their development: an overview of the problem. Geodynamics \& Tectonophysics 12 (3s), 754-768. doi:10.5800/GT-2021-12-3s-0552 


\title{
ТЕРРИТОРИАЛЬНЫЕ ГРУППИРОВКИ МЕСТОРОЖДЕНИЙ МИНЕРАЛЬНОГО СЫРЬЯ ЮГО-ВОСТОЧНОЙ СИБИРИ И НЕКОТОРЫЕ ПЕРСПЕКТИВЫ ИХ ОСВОЕНИЯ: ОБЗОР ПРОБЛЕМЫ
}

\author{
Ж.В. Семинский
}

Иркутский национальный исследовательский технический университет, 664074, Иркутск, ул. Лермонтова, 83, Россия

АНнотАЦИЯ. Целью работы является выделение и описание территориальных группировок минерального сырья южной части Восточной Сибири. Основу минерально-сырьевой базы составляют месторождения свинца, цинка, вольфрама, олова, молибдена, урана, меди, золота, лития, тантала, ниобия, серебра, флюорита, циркония, а также редких земель, железа, слюды, цветных камней, нефти, газа, угля, причем многие из них содержат значительную часть разведанных общероссийских запасов.

Месторождения полезных ископаемых локализуются в пределах тектонических структур Сибирской платформы (Тунгусская синеклиза, Непский свод, Черемховская, Приангарская впадины) и складчатых поясов, обрамляющих платформу с юга и юго-востока (Байкало-Патомский, Джида-Витимский и др.), которые формировались под воздействием плитотектонических и плюмтектонических процессов. Характеризуются полезные ископаемые территориальных группировок Приангарья, Присаянья, Прибайкалья и Забайкалья. Наиболее освоенными являются группировки, расположенные в южной половине рассматриваемой территории (Пришилкинская, Приаргунская, Еравнинская и др.). Группировки северной половины площади (Мамско-Бодайбинская и др.) освоены частично, в пределах существующих горнорудных районов, или освоение их находится в начальной стадии. На этих площадях в основном отсутствуют или слабо развиты пути сообщения, энергоснабжение и другие необходимые для функционирования горнодобывающих предприятий условия. Перспективы их связываются с экономическим развитием территорий, примыкающих к линии БАМа, и с добычей углеводородов в зоне нефтепровода Восточная Сибирь - Дальний Восток. На платформе месторождения полезных ископаемых формировались на этапах образования фундамента (Алданский, Анабарский, Шарыжалгайский щиты) и платформенного чехла (Тунгусская синеклиза, Непско-Ботуобинская антеклиза). В пределах складчатого обрамления рудообразование было связано с процессами субдукции, спрединга, коллизии, плюмтектоническими внутриплитными обстановками. Целесообразно обратиться к освоению малых месторождений и техногенного сырья на основе создания разведочно-эксплуатационных предприятий с применением компактных обогатительных установок и экспедиционных методов работы.

КЛЮЧЕВЫЕ СЛОВА: месторождения полезных ископаемых; геодинамические обстановки; территориальные группировки; минеральное сырье; перспективы развития; Восточная Сибирь

\section{1. ВВЕДЕНИЕ}

В настоящей работе дается краткая характеристика главных районов концентрации различных видов минерального сырья, рассматриваются особенности размещения и перспективы освоения месторождений полезных ископаемых обширного региона, включающего Иркутскую область, Республику Бурятия и Забайкальский край. Приводятся данные по геодинамическим и тектоническим позициям месторождений минерального сырья, а также краткая геологическая характеристика наиболее типичных и значимых объектов по районам их концентрации на базе проведенного автором регионального минерагенического анализа. При этом привлекаются данные по минерально-сырьевой базе, взятые из ряда официальных источников и обобщающих работ по административным подразделениям территории. Используются материалы автора, полученные в период с 1961 по 2012 г. в процессе полевых и тематических исследований по изучению месторождений железа, золота, урана, молибдена, вольфрама, флюорита, полиметаллов в различных районах Прибайкалья и Забайкалья и по перспективному районированию (рудные районы и узлы Ангаро-Илимский, Северо-Байкальский, Любавинско-Хапчерангинский, Усугли-Дарасунский, Амазаро-Могочинский, Широкинский, Урулюнгуйский, Балейский, Хангилай-Шилинский, Окинский и др.) [Seminsky, 2006, 2015, 2017; и др.]. При подготовке настоящего обзора использовано более восьмидесяти опубликованных и фондовых статей и монографий; в прилагаемом списке литературы указаны лишь обобщающие работы и работы, в которых те или иные научные исследования представлены впервые.

Все три вышеназванных административных образования входят в разряд важнейших в России по многим видам минерального сырья, насыщенности месторождениями и снабжают страну рядом полезных ископаемых. В Забайкальском крае имеется более 600 месторождений, по данным [Chechetkin et al., 2011], здесь содержится от общероссийских запасов (\%): лития - 80, флюорита - 38, молибдена - 27.8, меди - 25.8, урана 29.19 , тантала - 18 , ниобия - 16 , титана - 18 , свинца - 9 , золота - 7, цинка - 2.8, вольфрама - 4.6, угля - 1.6, цеолитов - 75. По объему разведанных запасов Забайкалье 
входит в число лидирующих горнорудных районов страны, являясь одним из основных поставщиков свинца, олова, золота, урана, молибдена. В недрах Республики Бурятия найдено и разведано около 700 месторождений, из которых 247 - золота. В месторождениях этого региона содержится от российских запасов (\%): цинка - 48, свинца - 24, молибдена - 37, вольфрама - 27 , флюорита - 16, хризотил-асбеста - 15 [General Information..., 2015]. В Иркутской области находится более 650 месторождений шестидесяти видов полезных ископаемых (золото, редкие металлы, полиметаллы, плавиковый шпат, поваренные и калийные соли, углеводороды, уран), при этом по углю, железу, каменным, калийным солям, тальку, апатиту область входит в первую пятерку регионов России; многие месторождения подготовлены к освоению [Mineral Resource Complex..., 2008; Mineral Resource Base..., 2010].

\section{2. МЕСТОРОЖДЕНИЯ ПОЛЕЗНЫХ ИСКОПАЕМЫХ В ГЕОТЕКТОНИЧЕСКИХ СТРУКТУРАХ РЕГИОНА}

В целом по минерально-сырьевой базе Юго-Восточной Сибири нужно отметить следующее. Среди месторождений железа большое значение имеют гидротермальные месторождения Ангаро-Илимского района, железистые кварциты, распространенные на северовостоке региона в Чаро-Токкинском районе. Значительными являются месторождения меди: медистые песчаники и медно-титано-ванадиевые месторождения Удокана [General Information..., 2015; Laverov, 1995].

Свинцово-цинковые месторождения, имеющие в регионе весьма широкое распространение, относятся к формации жильных сульфидно-полиметаллических гидротермальных руд (Юго-Восточное Забайкалье) и к колчеданно-полиметаллической формации стратиформных месторождений, залегающих в терригеннокарбонатных и вулканогенных толщах на западе Байкало-Патомской области и в Центральном Забайкалье [Laverov, 1995].

Месторождения вольфрама, молибдена и олова, весьма типичные для южных и восточных районов Забайкалья, относятся к вольфрамит-кварцевой, касситерит-кварцевой, касситерит-вольфрамит-кварцевой, касситерит-сульфидной, кварц-молибденитовой и вольфрамит-молибденитовой рудным формациям. Золото распространено, хотя и неравномерно, на всей территории. Однако наиболее насыщена им площадь бассейна p. Шилки, где преобладают золото-кварц-сульфидная и золото-кварцевая формации, представленные типичными жильными гидротермальными месторождениями. Крупные россыпные и коренные месторождения находятся в северной части региона (Бодайбинский (Ленский), Муйский районы). В первом из них распространены полигенные и полихронные золоторудные месторождения золото-кварцевой и золото-малосульфидной формаций. Месторождения золота магматогенно-гидротермальных систем широко представлены в юго-восточных районах Забайкалья [Konstantinov, 2010; Laverov, 1995].
Забайкальский регион Восточной Сибири является одним из базовых в стране по запасам урана. Наиболее значимые месторождения настуран-молибденитфлюоритовой, настуран-гидрослюдистой формаций локализуются в двух крупных урановорудных районах Забайкалья: Урулюнгуйском и Витимском [Samovich et al., 2012]. В первом из них разрабатываются подземным способом гидротермальные месторождения Стрельцовского рудного поля. Месторождения Витимского ураноносного района отрабатываются сравнительно дешевым способом - подземным выщелачиванием. Забайкалье также принадлежит к флюоритоносным районам: месторождения кварц-флюоритовой формации пользуются наиболее широким распространением в центральной и южной частях региона. Из других полезных ископаемых необходимо отметить месторождения мусковита в Байкало-Патомском поясе, а также асбеста, поделочного сырья (нефрит, чароит и др.); значительную ценность представляют месторождения тантала, ниобия, редких земель в Восточном Саяне и Забайкалье, каменных и калийных солей, магнезита.

Следует особо отметить энергетическое сырье Восточной Сибири. Прежде всего, это хорошо известные издавна месторождения каменного и бурого угля на южной окраине Сибирской платформы, а также объекты угленосных мезозойских впадин «забайкальского типа». Особое значение в последнее десятилетие приобрели нефтегазовые месторождения юго-восточной и южной частей Сибирской платформы в Непском и Прибайкальском районах. В ближайшее время при определенных вложениях и активной эксплуатации месторождений углеводородного сырья (УВС) эта отрасль может стать ведущей в регионе.

Размещение рудных узлов и месторождений показывает, что они распространены неравномерно [Plushchev, 2001].

Наибольшей рудонасыщенностью характеризуется юго-восточная часть рассматриваемой территории Восточной Сибири, где находится основное количество месторождений и рудопроявлений молибдена, олова, свинца, цинка, флюорита, золота, вольфрама, редких элементов и других полезных ископаемых. Это рудные узлы Жирекенский (молибден), Амазаро-Могочинский (золото, молибден, уран), Усугли-Дарасунский (золото, флюорит), Карийский (золото), Оловский (уран), Балейский (золото), Шерловогорский (олово, полиметаллы), Кукульбейский (вольфрам, флюорит, редкие металлы), Любавинско-Хапчерангинский (золото, олово), Кличкинский (полиметаллы), Стрельцовский (Урулюнгуйский) (уран, молибден, флюорит), Абагайтуйский (флюорит) и др. В северной, центральной частях Забайкалья и в Прибайкалье плотность распространения рудных узлов меньше, но и там находятся несколько крупных рудных районов и узлов (Бодайбинский и Муйский золоторудные, Северо-Байкальский свинцово-цинковый, Удоканский меденосный, Мамский слюдоносный и др., Ангаро-Илимский железорудный, 
Непско-Ботуобинский нефтегазоносный). Одиночные крупные рудные узлы выявлены на юго-западе и в центре (Джидинский, Озернинский).

Рассматриваемая территория занимает значительные площади двух геотектонических областей - Сибирской платформы (Северо-Азиатского кратона) и плане тарного Центрально-Азиатского складчатого пояса. Западная часть региона находится на Сибирской платформе и включает Анабарский, Алданский, Шарыжалгайский щиты, Тунгусскую синеклизу, Непско-Ботуобинскую антеклизу, Присаянский, Прибайкальский краевые прогибы, Черемховскую, Приангарскую впадины.

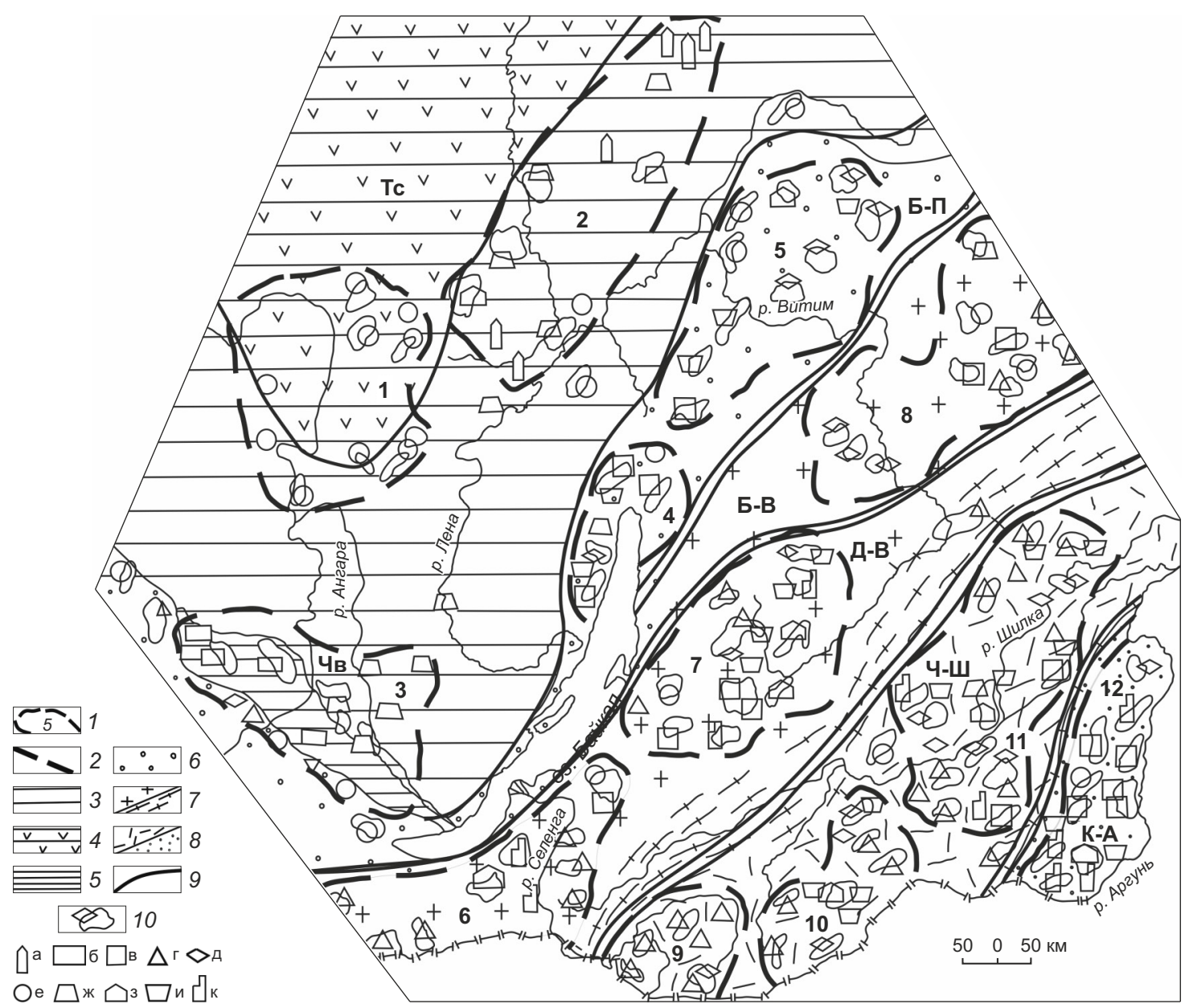

Рис. 1. Схема расположения территориальных группировок и рудных узлов Восточной Сибири (с использованием [Seminsky, 2006, 2015, 2017; Plushchev, 2001]).

1 - территориальные группировки: 1 - Ангаро-Илимская, 2 - Непская, 3 - Присаянская, 4 - Северо-Байкальская, 5 - МамскоБодайбинская, 6 - Селенгинская, 7 - Еравнинская, 8 - Чаро-Муйская, 9 - Чикойская, 10 - Даурско-Агинская, 11 - Пришилкинская, 12 - Приаргунская; 2 - границы группировок минерального сырья; 3-8 - тектонические подразделения платформы и складчатой области: 3 - структуры чехла платформы, в том числе: 4 - Тунгусская синеклиза (Тс), 5 - Черемховская впадина (Чв), 6-8 - складчатые (минерагенические) пояса: 6 - Байкало-Патомский окраинно-кратонный (Б-П), 7 - Байкало-Витимский (Б-В) и Джида-Витимский (Д-В) коллизионно-аккреционные, 8 - Чикой-Шилкинский (Ч-Ш) и Керуленско-Аргунский (К-А) внутриплитные плюмтектонические; 9 - границы поясов; 10 - рудные узлы и отдельные месторождения: а - нефть, газ, б - уголь, в - цветные металлы (Cu, Al, Pb, Zn, Ni), г - редкие и лигирующие металлы (Sn, W, Mo, Hg, Ta, Nb), д - благородные металлы (Аu, $\mathrm{Ag}, \mathrm{Pt}), \mathrm{e}$ - черные металлы (Fe,Ti, Mn), ж - соли, з - слюды, и - радиоактивные металлы (U, Th), к - драгоценные и поделочные камни (алмаз, нефрит, малахит, чароит).

Fig. 1. Schematic map of East Siberia showing the clusters of mineral deposits and ore nodes (after [Seminsky, 2006, 2015, 2017; Plushchev, 2001]).

1 - clusters of mineral deposits: 1 - Angara-Ilim, 2 - Nepa, 3 - Sayan, 4 - Severo-Baikalsk, 5 - Mama-Bodaibo, 6 - Selengina, 7 Yeravnino, 8 - Chara-Muya, 9 - Chikoi, 10 - Dauria-Aga, 11 - Shilka, 12 - Argun; 2 - boundaries of clusters; 3-8 - tectonic structures of the platform and folded area: 3 - structures of the platform cover, including: 4 - Tunguska syncline (Tc), 5 - Cheremkho depression (Чв), 6-8 - folded (mineragenic) belts: 6 - Baikal-Patom marginal cratonic belt (Б-П), 7 - Baikal-Vitim (Б-В) and Dzhida-Vitim (Д-В) collision-accretion belts, 8 - Chikoi-Shilka (Ч-Ш) and Kerulen-Argun (K-A) intraplate plume tectonic belts; 9 - boundaries of the belts; 10 - ore nodes and deposits: a - oil, gas, б - coal, в - nonferrous metals ( $\mathrm{Cu}, \mathrm{Al}, \mathrm{Pb}, \mathrm{Zn}, \mathrm{Ni}$ ), $\mathrm{r}$ - rare-earth and ligated metals ( $\mathrm{Sn}, \mathrm{W}$, Mo, $\mathrm{Hg}$, Ta, Nb), д - noble metals ( $\mathrm{Au}, \mathrm{Ag}, \mathrm{Pt}$ ), е - ferrous metals (Fe, Ti , Mn), ж - salts, з - micas, и - radioactive metals (U, Th), к - precious and semi-precious stones (diamond, jade, malachite, charoite). 
Особое значение для эндогенной минерагении имеют вулканические и плутонические комплексы трапповой формации, развитые в пределах Тунгусской синеклизы и в ее южном и восточном обрамлении. Южная и юго-восточная части платформы представляют собой переработанную тектоническими процессами окраину кратона, к которой затем с юга и юго-востока примыкают складчатые сооружения Центрально-Азиатского пояса, сформировавшиеся в результате плитотектонических субдукционных, спрединговых, коллизионных и плюмтектонических процессов и сложенные разнообразными по природе и размерам террейнами, сшивающими и перекрывающими комплексами (рис. 1). На этой территории представлены протяженные складчатые пояса различной природы, вытянутые преимущественно в северо-восточном направлении.

Перечисленные тектонические элементы определяют минерагеническое районирование - на платформе это минерагенические области (Тунгусская, Присаянская, Алдано-Становая), в складчатых системах - минерагенические пояса различных геодинамических обстановок. Минерагеническое районирование рассматриваемого региона проводилось неоднократно многими исследователями. В 1999-2004 гг. такая работа была выполнена большим коллективом специалистов России, США, Китая, Японии, Монголии, Южной Кореи при реализации международного проекта «Металлогения и тектоника Северо-Восточной Азии», координаторы академики РАН А.И. Ханчук и М.И. Кузьмин. Были описаны десятки месторождений полезных ископаемых, выделены металлогенические пояса. Составленные карты имели мелкий масштаб (1:15000000); основной целью проекта было определение геодинамических обстановок формирования месторождений полезных ископаемых [Belichenko et al., 1994; Parfenov, Kuzmin, 2001; Nokleberg, 2010]. В пределах Юго-Восточной Сибири автором проводилось минерагеническое районирование в более детальном масштабе, были выделены и описаны подразделения двух иерархических уровней: минерагенические (металлогенические) пояса как элементы первого порядка и входящие в их состав рудные пояса. Их описание приведено в ряде работ [Seminsky, 2006, 2017]. Минерагенические пояса по геодинамической принадлежности отнесены к трем типам: складчато-надвигового орогенеза на деформированной опущенной окраине кратона (Байкало-Патомский), аккреционноколлизионной природы (Джида-Витимский, БайкалоВитимский), внутриплитные, связанные с деятельностью Центрально-Азиатского суперплюма (Чикой-Шилкинский, Керуленско-Аргунский). Ранее Л.М. Парфенов с соавторами, И.В. Гордиенко, А.Н. Булгатов и др. выделили и описали Байкало-Патомский складчато-надвиговый и другие пояса Восточной Сибири [Parfenov, 1994; Parfenov et al., 1995; Parfenov, Kuzmin, 2001]. Более детально геодинамические особенности золоторудных районов Юго-Восточной Сибири, входящих в состав указанных минерагенических поясов, были описаны A.T. Корольковым [Korol'kov, 2007].

\section{3. ОБЩАЯ ХАРАКТЕРИСТИКА ТЕРРИТОРИАЛЬНЫХ ГРУППИРОВОК МИНЕРАЛЬНОГО СЫРЬЯ}

На фоне тектоно-минерагенического районирования отчетливо выделяются площади, которые отличаются высокой концентрацией месторождений минерального сырья (рис. 1), характеризуются определенным комплексом полезных ископаемых, тяготеющих к конкретным экономическим районам и в разной степени благоприятных для создания горнодобывающих и перерабатывающих комплексов в настоящее время или в ближайшем будущем. Краткая характеристика выделенных территориальных группировок минеральных ресурсов приводится в Прил. 1, табл. 1 .

Рассматривая территориальные группировки минерального сырья по отношению к тектоническим подразделениям платформы и минерагеническим поясам складчатых сооружений, можно видеть, что они не всегда вписываются в их границы, т.к. при их выделении в значительной степени учитывались распределение объектов минерального сырья и географо-экономические условия. Перспективы освоения месторождений полезных ископаемых выделенных группировок различны и зависят от степени экономического развития площади, востребованности и ценности минерального сырья, которое в них концентрируется. Ниже рассматриваются наиболее значимые полезные ископаемые и проблемы освоения месторождений в крупных территориальных группировках региона с использованием официальных опубликованных материалов геологических служб Иркутской области, Республики Бурятия и Забайкальского края [Chechetkin, Trubachev, 2013; General Information, 2015; Mineral Resource Complex..., 2008].

\section{4. ТЕРРИТОРИАЛЬНЫЕ ГРУППИРОВКИ НА СИБИРСКОЙ ПЛАТФОРМЕ}

Эти группировки охватывают окраины Тунгусской синеклизы и прилежащие территории, где наиболее интенсивно выражены разрывные нарушения и трапповый интрузивный магматизм. Разломы, часто отчетливо проявленные лишь в фундаменте, ограничивают впадины и поднятия платформы, а при пересечении с разрывами, поперечными к границам, образуют разломные узлы, благоприятные для процессов формирования эндогенных месторождений полезных ископаемых. Значительным распространением в приграничной зоне Тунгусской синеклизы пользуются силлы траппов и трубчатые структуры - диатремы. На этой территории выявлены промышленные месторождения нефти, газа, алмазов, железа, медно-никелевых руд, угля, солей, редкоземельных металлов. Месторождения углеводородного сырья преобладают на восточной окраине Тунгусской синеклизы, сульфидные медноникелевые месторождения локализуются на северной и северо-западной окраинах синеклизы (Норильский рудный район), железорудные - концентрируются на ее южном замыкании. Разнообразные рудные и нерудные месторождения формировались также на южной 
окраине платформы в пределах Присаянской впадины и выступов фундамента платформы. На рассматриваемой части платформы выделяются три территориальные группировки минерального сырья.

Непская группировка примыкает с востока к Тунгусской синеклизе (Непский свод). В ее пределах находятся основные нефтегазовые месторождения Восточно-Сибирской провинции (37 месторождений УВС, в том числе Верхночонское, Ковыктинское, Дулисьминское); треть месторождений однокомпонентные. Прогнозные извлекаемые запасы оцениваются по нефти и конденсату в 2.05 млрд т (10 \% от общероссийских), по газу - 7.8 трлн куб. м. Дулисьминское месторождение содержит 15.9 млн т нефти, крупнейшее по запасам газа Ковыктинское - 2.7 трлн куб. м, Чонское - 82.2 млн т нефти. В связи с необходимостью обеспечения сырьем нефтегазопровода «Восточная Сибирь - Тихий океан» (BCTO) эта группировка имеет большие перспективы развития, хотя находится на значительном удалении от промышленно развитых районов и путей сообщения, но в непосредственной близости от ВСТО. Наиболее удалены месторождения нефти (Непско-Ботуобинский район этой группировки). Предполагается расширение геологических работ, т.к. запасы нефти составляют лишь около 30 \% и газа 70 \% от требуемых. При этом добывающая отрасль до конца еще не сформирована.

В этой группировке находится крупнейшее месторождение каменных и калийных солей. Лучшим по всем параметрам является самое крупное в мире по запасам (70 млрд т) и второе по чистоте Непское месторождение калийных солей. В отдельных участках солевые горизонты залегают на глубине всего 6 м от поверхности. Прослои несоляных пород составляют первые миллиметры. Отсутствие транспортной структуры отодвигает освоение этого объекта до строительства шоссейных и железных дорог. Строительство автотрассы «Вилюй», которая должна проходить по центру этой группировки, постоянно тормозится из-за отсутствия денежных средств.

Ангаро-Илимская группировка находится на южном замыкании Тунгусской синеклизы, где эффузивный магматизм синеклизы сменяется интрузивами траппов и криптовулканическими структурами. Группировка рассматривается как наиболее крупная на юге Восточной Сибири железорудная база (месторождения Коршуновское, Рудногорское, Нерюндинское, Капаевское и др.), где эксплуатируются три месторождения и могут быть вовлечены в разработку не менее десяти объектов. Определяющим геолого-тектонические особенности этой территории является ее положение в южной пограничной зоне Тунгусской синеклизы. В двух широких зонах дугообразных разломов (Канско-Кутского и Тасеевско-Непского) на пересечении с поперечными разрывами северо-западного, близмеридионального и северо-восточного простирания локализуются узлы диатрем, в которых формировались штокверково-жильные залежи и сопровождающие их внутрипластовые тела магнетитовых руд. Диатремы представляют собой трубчатые каналы, выполненные раздробленными осадочными и брекчированными изверженными породами и туфами с подводящими дайкообразными каналами (эксплозивно-интрузивные образования). Некоторые рудные поля сложены несколькими сближенными или расположенными в одной зоне разломов диатремами, например Рудногорское месторождение. Разведано 11 месторождений, в которых запасы руды составляют 1.9 млрд т. Всего же запасы железа Ангаро-Илимского района оцениваются в 15.5 млрд т [Mineral Resource Complex..., 2008]. Наиболее крупные месторождения Капаевское, Нерюндинское и Поливское удалены от железной дороги на 100-150 км. Эксплуатируются Коршуновское, Рудногорское и Татьянинское месторождения. На Капаевском месторождении запасы железных руд на 1965 г. составляли 117.6 млн т. Дальнейшее развитие производства по добыче железа возможно при вовлечении в эксплуатацию крупных месторождений района, для чего необходимо развитие железнодорожной и энергетической сетей.

Присаянская группировка протягивается в предгорьях Восточного Саяна в северо-западном направлении вдоль Транссибирской железнодорожной магистрали более чем на 600 км. Охватывает широкую полосу по обе стороны от Присаянской зоны разломов, включая Черемховскую угленосную впадину и краевую часть Шарыжалгайского щита платформы с различными эндогенными месторождениями. В северо-восточном крыле разлома, в породах чехла платформы, преобладают экзогенные месторождения, тогда как в зоне разлома и в юго-западном крыле, в породах фундамента кратона, распространена преимущественно эндогенная минерализация. Издавна известными здесь и эксплуатируемыми полезными ископаемыми являются уголь и каменные соли. Большое значение имеют месторождения тантала, лития, цезия, рубидия, ниобия, талька, магнезита. Уголь концентрируется в 22 месторождениях (Черемховское, Ишидейское, Азейское, Мугунское и др.) и добывается на четырех месторождениях открытым способом. Разведанные запасы составляют около 5.2 млрд т. Месторождения характеризуются высокой угленасыщенностью, угольные пласты залегают неглубоко (около 100 м). Присаянье - старый соленосный район России, содержащий около 50 \% запасов страны (5 наиболее значимых месторождений Усольское, Тыретское и др.). В разрезе содержится до 25 пластов. В группировке 11 крупных редкоземельных месторождений (Белозиминское, Среднезиминское, Гольцовое, а также Вишняковское в Тайшетском районе и др.). Крупное Белозиминское месторождение является комплексным апатит-редкометалльным. В пределах этой группировки находятся уникальное по качеству и запасам Савинское месторождение магнезитов и Онотское месторождение талька. Имеются непромышленные месторождения урана [Samovich et al., 2012]. Месторождения угля, каменных солей находятся в выгодных географо-экономических условиях 
(вдоль линии Транссибирской магистрали). Месторождения редких земель могли бы полностью обеспечить потребность страны, но не эксплуатируются из-за удаленности от транспортных коммуникаций на 100150 км и часто низкого качества руд.

\section{5. ТЕРРИТОРИАЛЬНЫЕ ГРУППИРОВКИ В ПЛАНЕТАРНОМ ЦЕНТРАЛЬНО-АЗИАТСКОМ СКЛАДЧАТОМ ПОЯСЕ}

Эта территория включает Восточный Саян, Байкальскую горную область и Забайкалье. В тектоническом плане эти районы объединяет то, что их большая часть представляет собой орогенно-коллизионные сооружения, обрамляющие Северо-Азиатский кратон. Лишь с севера и северо-запада примыкают структуры окраины кратона. На плито-тектоническом этапе развития возникла система террейнов, сшивающих и перекрывающих комплексов [Belichenko et al., 1994; Parfenov et al., 2003; Obolensky et al., 2006; Gordienko, 2014], что создало благоприятную гетерогенную обстановку для проявления процессов рудообразования. Наращивание континента происходило на восток от границы кратона, плюмтектонический этап характеризовался интенсивными процессами интрузивного магматизма и вулканизма в узлах пересечения разноориентированных разломов, где и формировались рудные узлы. В пределах складчатой области наибольшее значение имеют месторождения золота, свинца, цинка, меди, урана, флюорита, олова, вольфрама, молибдена, редких земель, нефрита, асбеста и др. Формирование их происходило в различных геодинамических обстановках в широком интервале времени от архея до кайнозоя. Смена древних (протерозойских и раннепалеозойских) минерагенических эпох более молодыми (позднепалеозойскими и мезозойскими) также имела тенденцию в направлении с запада на восток.

Как упоминалось выше, в регионе выделяются три типа минерагенических поясов различной природы: окраинно-кратонные (складчато-надвиговые), коллизионно-аккреционные и внутриплитные (эпикратонные плюмтектонические). Наблюдается хорошо известная зональность, выражающаяся в примыкании к деструктированной окраине кратона складчатых поясов различного строения. В Прибайкалье к БайкалоПатомскому складчато-надвиговому поясу примыкает Байкало-Витимский, а затем Джида-Витимский аккреционно-коллизионные пояса. Первый имеет сложное строение, обусловленное выходами на поверхность пород докембрийских выступов - террейнов фундамента кратона, перекрытых или соединенных более молодыми образованиями. Вторая группа орогенных поясов представляет собой совокупность деформационных структур, возникших на месте различных океанических бассейнов при аккреции террейнов к континенту и при коллизии. Последовательная смена древних орогенных поясов более молодыми по мере удаления от окраины кратона отражает общую тенденцию разрастания континента. Третья группа поясов формировалась в основном после закрытия Монголо-Охотского океана в среднеюрско-раннемеловое время на внутриплитном этапе развития региона. Внутриплитные орогенные пояса на территории Юго-Восточной Сибири были связаны с активной деятельностью Северо-Азиатского суперплюма, который в позднепалеозойско-мезозойское время был расчленен на ряд звеньев (Забайкальское и др.). Чикой-Шилкинский пояс охватывает широкую зону Монголо-Охотской сутуры. КеруленскоПриаргунский пояс занимает крайнюю юго-восточную часть территории и продолжается в северные районы Восточной Монголии и Китая. Континентальный внутриплитный тектонический режим, охвативший практически всю территорию в позднем палеозое - мезозое, привел не только к формированию весьма своеобразных по внутреннему строению орогенов, но и к существенным преобразованиям на территории более древних орогенных поясов. Минерагения выделенных тектонических структур тесно связана с историей развития и их строением.

Важной особенностью минерагенических поясов является присутствие в них древних блоков-террейнов различных размеров, являющихся, как известно, своеобразными концентраторами магматических и рудных процессов. Обладая повышенной жесткостью, они подвергаются (особенно по окраинам) интенсивному дроблению, что приводит к образованию глубокопроникающих разломов, выводящих к поверхности магму разного состава и рудообразующие флюиды. К таким структурам в надвигово-складчатых поясах окраины кратона и в позднерифейских орогенных поясах относятся Муйский, Гарганский, Шарыжалгайский и более мелкие террейны.

\section{1. Байкало-Патомский минерагенический пояс}

Континентальная окраина кратона на территории Юго-Восточной Сибири включает ряд складчато-надвиговых поясов сложного строения в Прибайкалье и Восточном Саяне. Процессы рудообразования часто характеризуются значительной длительностью и полигенностью, что обусловлено длительностью проявления деструкции окраины кратона и влиянием коллизионных и субдукционных явлений при формировании причленяющихся с юга орогенных поясов. В БайкалоПатомском минерагеническом поясе выделены две территориальные группировки минерального сырья.

Мамско-Бодайбинская группировка находится на северо-востоке пояса и по комплексам месторождений полезных ископаемых разделяется на две части - северо-восточную слюдоносную и юго-западную золотоносную. Первая из них именуется Мамским слюдоносным районом, поясом протяженностью около 200 км, содержащим более 10 значительных месторождений листовой слюды и ряд мелких. Слюдосодержащие пегматитовые тела представлены жилами согласными и секущими, телами неправильной формы, гнездами. Добыча была прекращена в начале 2000-х гг. в связи с нерентабельностью. Юго-западную часть рассматриваемой 
группировки занимает Бодайбинский золотоносный район, являющийся в стране одним из наиболее известных и богатых по запасам золота. Более ста пятидесяти лет здесь добывалось золото из россыпей, многие из которых практически отработаны, и перспективы сейчас связываются с коренными месторождениями: это Сухой Лог (одно из самых крупных в России), Вернинское, Высочайшее, Догалдынское, Кавказ, Мукодек, Первенец, Юбилейное. Ряд месторождений локализуются в пределах Хомолхино-Илигирской и ВернинскоНевской рудных зон. Отрабатываются месторождения Высочайшее, Западное и Невское. По запасам рудного золота рассматриваемая группировка является крупнейшей в стране (более 15 т в коренных месторождениях); ежегодно дает около $11 \%$ добычи в России. На месторождении Сухой Лог, содержащем 28 \% запасов золота России, на 2016 г. запасы золота составили 2700 т, серебра - 1530 т, из них балансовые запасы золота 1942.6 т. Запасы Вернинского месторождения на 2016 г. составляли 221.7 т. Планируется, что запасов россыпного золота хватит на 15 лет, а вместе с техногенными месторождениями - на 20-30 лет. По подсчетам, в россыпях находится $15 \%$, а в коренных месторождениях - более 75 \% запасов золота Бодайбинского района. Несмотря на большие ресурсы россыпного и коренного золота, значительных затрат требует перевод этих ресурсов в разведанные запасы. Район относится к малообжитым, до железнодорожной станции Таксимо 335 км. Существует дефицит электроэнергии. В настоящее время проводятся работы по развитию инфраструктуры, строятся автодороги, ЛЭП, реконструируются имеющиеся здесь ГЭС и др.

Вторая группировка - Северо-Байкальская - включает месторождения: колчеданно-полиметаллической формации (Холоднинское и др.) и сульфидно-медноникелевые (Чайское). Здесь распространен габбро-перидотитовый магматический комплекс, с которым связана рудная минерализация. Месторождение Холоднинское находится на юго-западной окраине крупного Бодайбинского прогиба в метаморфизованных осадках протерозоя и представлено согласными рудными залежами среди черносланцевых толщ. Эксплуатация крупнейшего в России Холоднинского свинцово-цинкового месторождения затягивается в связи с экологической проблемой: оно расположено в 75 км от Байкала в центральной экологической зоне Байкальской природной территории. Месторождение содержит 2.01 млн т свинца и 13.34 млн т цинка, являясь соответственно вторым и первым в стране по запасам этих металлов, содержит 46 \% мировых запасов цинка и 14 \% - свинца.

\section{2. Байкало-Витимский минерагенический пояс}

Пояс, относящийся к аккреционно-коллизионному типу, представляет собой совокупность деформационных структур, возникших на месте различных океанических бассейнов при аккреции террейнов к континенту или при коллизии. Н.Л. Добрецов с соавторами [Dobretsov et al., 2001] отмечают, что пояса этого типа представляют собой блоки микроконтинентов, сцементированные субдукционно-аккреционными и аккреционно-коллизионными комплексами, пронизанные коллизионными и постколлизионными гранитами и часто перекрытые осадочными толщами.

В основном в позднепротерозойское и кембро-силурийское время образовались сшивающие и перекрывающие комплексы, проявились и более поздние девонраннекарбоновые процессы метаморфизма и рифтообразования. Значительные месторождения полезных ископаемых сосредоточены в одной территориальной группировке.

Чаро-Муйская группировка занимает северо-восток региона, на границе складчатой области и Алданского щита, и состоит из двух частей. В Чарском районе (на севере) находятся крупные месторождения меди (Удоканское и др.), железистых кварцитов (Южно-Сулуматское и др.), редких и редкоземельных элементов. Удоканское месторождение содержит свыше 26 млн т меди, что составляет пятую часть всех запасов меди России, и является третьим в мире по запасам меди. Оно представлено пластовыми рудными телами, залегающими в пределах крупной впадины, сложенной метаморфизованными кварц-карбонатными песчаниками раннего протерозоя. Расположено в 30 км от линии БАМа. В 2020 г. начались вскрышные работы, подготавливается карьер, промышленная эксплуатация намечена на 2022 г. Здесь же располагаются Чинейское месторождение медистых и железистых габброидов, в котором запасы ванадия и качество руд являются уникальными, Катугинское месторождение криолитциркон-тантал-ниобиевых редкоземельных руд, по запасам тантала и иттрия крупнейшее в мире. Месторождения этой группировки могут стать сырьевой базой черной металлургии. Комплексное освоение Чинейского, Удоканского, Катугинского месторождений при участии государства в развитии инфраструктуры может быть рентабельным и привлекательным для инвесторов. В этом районе железная дорога уже подошла к основным месторождениям, но имеет ограничения по пропускной способности, требует ремонтных работ. В плохом состоянии автомобильные дороги, имеется значительная энергодефицитность, требуется реконструкция аэродромного комплекса.

Вторая часть рассматриваемой группировки - Муйская - известна как база золотодобывающей промышленности. Своеобразную «рудоконцентрирующую» роль в Байкало-Витимском минерагеническом поясе играют микроконтиненты (срединные массивы), в частности Муйский террейн, в котором находится КедровоИрокиндинский рудный узел - золото-малосульфидное месторождение Ирокиндинское и другие, а также россыпи. Ирокиндинское месторождение, содержащее около 150 золоторудных жил в гнейсах и сланцах архея, разрабатывается подземным способом. Запасы Ирокинды оцениваются в 9.5 т, месторождения Кедрового (около 100 жил) - в 6 т. Молодежное месторождение хризотил-асбеста, Голюбинское и Буромское месторождения 
нефрита повышают перспективы этого района. Линия БАМа проходит по центральной части площади. Однако территория характеризуется суровыми природными условиями (длительный зимний период - до 10 месяцев, разрушительные современные рельефообразующие процессы, перемещение больших масс рыхлого материала, сейсмоактивность и др.); необходимо совершенствование транспортной, социальной и других видов инфраструктуры.

\section{3. Джида-Витимский минерагенический пояс}

Пояс протягивается от южного побережья Байкала на северо-восток в бассейн р. Витим. Имеет аккреционно-коллизионную природу, однако существенно отличается от предыдущего тем, что в ряде районов, например в Южном Прибайкалье, достаточно широко проявились внутриплитные процессы тектоно-магматической активизации мезозойского возраста, связанные с деятельностью Центрально-Азиатского плюма; сказывается также близость Чикой-Шилкинского внутриплитного орогена. В пределах пояса присутствуют блоки докембрийского фундамента, сшивающие и перекрывающие комплексы палеозойского и раннемезозойского возраста. Выделяются две территориальные группировки с промышленными месторождениями полезных ископаемых.

Еравнинская группировка занимает центральную часть пояса. Здесь находится Озерное месторождение полиметаллов с серебром и золотом, которое является вторым по запасам цинка в России (после Холоднинского). Месторождение уникально по запасам свинца (1.6 млн т), цинка (8.3 млн т); запасы серебра составляют 4.6 тыс. т. Пластовые и жилообразные рудные тела залегают на нескольких уровнях в пределах синклинали, сложенной нижнекембрийскими вулканогенно-осадочными породами. Руды относятся к труднообогатимым из-за тонкого срастания в них минералов цинка и свинца. Добыча начиналась в 2011 г., но была незначительной: цинка - 800 т, свинца - 100 т, серебра 0.3 т. По условиям лицензионного соглашения основные строительные и горнокапитальные работы и ввод в эксплуатацию ГОКа запланированы на 2020-2023 гг., а в 2024 г. предприятие должно выйти на проектную мощность. На Назаровском месторождении установлено рудное золото. В целом в рудных объектах рассматриваемой группировки прогнозные ресурсы золота составляют 30 т [Gordienko et al., 2013]. Здесь же находится промышленное Эгитинское месторождение флюорита, на которое в Российской Федерации приходится 8.4 \% добычи. На месторождении выявлено 23 рудных тела среди нижнекембрийских вулканогенно-осадочных пород; балансовые запасы составляют 1.432 млн т. Урановая минерализация представлена непромышленным Буяновским месторождением. Большинство месторождений Еравнинской группировки располагаются в сравнительно освоенном регионе.

Селенгинская группировка включает Джидинский рудный узел (семь месторождений), где расположены
Первомайское молибденовое, Инкурское и Холтосонское вольфрамовые месторождения, которые разрабатывались с 30-х гг. прошлого столетия; сейчас законсервированы. Штокверковые и жильные рудные тела этого узла концентрируются вокруг Первомайского гранитного массива, составляя единую рудно-магматическую систему. После пересчета запасов возможно возобновление эксплуатации месторождений этого рудного узла, что приведет к дальнейшему развитию горнодобычных работ. Кроме того, в этой группировке находятся вольфрамовые россыпи, Мало-Ойногорское и Булуктаевское вольфрам-молибденовое, Наранское флюоритовое, Гусиноозерское угольное и другие месторождения полезных ископаемых. Установлены повышенные концентрации золота в рудопроявлениях кварц-пирит-халькопиритовой минерализации Золотая Горка, Барун-Нарын и др. Территория относится к сравнительно освоенным, район по-прежнему рассматривается как промышленный узел минерально-сырьевого профиля [Gordienko et al., 2017].

\section{4. Чикой-Шилкинский минерагенический пояс}

Пояс вытягивается вдоль Монголо-Охотского разлома, охватывая системы разрывных нарушений, отходящих от сутуры на юго-запад или субпараллельных ей, и относится к внутриплитным плюмтектоническим поясам. В связи с тектоническими движениями в зоне сутуры в пределах пояса формировались крупные крутопадающие разломы и надвиги, происходило образование зон рифтинга - систем грабенов, выполненных терригенными и вулканогенными породами, часто с угленосными толщами. Локальные поднятия Забайкальского плюма - струи тепломассопереноса обусловили положение центров магматической деятельности (вулканотектонических структур, плутонических центров) и рудных узлов [Seminsky, 2004, 2015]. Для Чикой-Шилкинского минерагенического пояса характерна высокая рудонасыщенность, в его составе выделены три территориальные группировки минерального сырья.

Пришилкинская группировка вытянута на северовосток по обоим берегам р. Шилки, является наиболее крупной и богатой разнообразными месторождениями полезных ископаемых. Эта площадь на многих участках благоприятна по доступности для эксплуатации месторождений минерального сырья. Здесь находятся старые горнорудные районы, освоение которых происходило еще в XVII-XVIII вв., и действующие в настоящее время горнорудные комбинаты. Наиболее значительны месторождения золота, свинца, цинка, серебра, вольфрама, олова, урана, флюорита, так, на этой площади находятся более 400 различных по масштабам месторождений и рудопроявлений полиметаллической минерализации. Группировка охватывает значительные части золото-молибденового, оловянновольфрамового и полиметаллического рудных поясов, выделенных в прошлом веке академиком С.С. Смирновым. Здесь представлено большое разнообразие 
геолого-промышленных и формационных типов месторождений полезных ископаемых, которые связаны с внутриплитными плутоническими и вулканическими процессами. Характерно линейно-узловое распределение рудных объектов: крупные промышленные месторождения коренного и россыпного золота сосредоточены в Усугли-Дарасунском, Широкинском, Карийском, Балейском и других рудных узлах. Находящиеся здесь месторождения золота разрабатывались или продолжают разрабатываться в настоящее время, несмотря на это, прогнозные ресурсы во много раз превышают разведанные запасы.

Дарасунский узел включает Дарасунское, Теремкинское, Талатуйское месторождения золота с жильными телами, связанными с центрами вулкано-плутонической деятельности, и Усуглинское месторождение флюорита. Золоторудные жильные тела локализуются в пределах очагово-купольных построек мезозойского возраста. Запасы золота в Дарасунском рудном поле на 2018 г. составляют 56 т. Крупное Ново-Широкинское золото-полиметаллическое месторождение, находящееся на юго-восточной окраине рассматриваемой группировки, содержит промышленные запасы золота, серебра, свинца и цинка. Жильные рудные тела локализуются в нескольких рудных зонах северо-западного простирания среди вулканитов одноименной впадины. По полиметаллам это месторождение является самым крупным в Забайкальском крае. В семнадцати рудных телах содержится 348 тыс. т свинца, 165 тыс. т цинка, 30.7 т золота и 810 т серебра. На этом лидирующем по добыче золота в Забайкалье месторождении разработка проводится подземным способом. Балейское рудное поле объединяет Балейское и Тасеевское месторождения. Месторождения включают серию рудных жил в осадочных породах грабена и гранитного фундамента (более протяженных). Разработки велись с тридцатых годов прошлого столетия; было извлечено около 200 т золота (Балейское месторождение), остаточные запасы на 2015 г. составляли 40.3 т. В восточной части группировки находится месторождение золота Уконик, рудные тела которого локализуются в экзоконтактовой зоне гранитного массива среди архейских метаморфических пород. Запасы золота оцениваются в 24.5 т, отрабатывать их планируется подземным способом с 2023 г. после проведения реконструкции. Крупными по запасам молибдена являются Жирекенское, Шахтаминское и Бугдаинское месторождения. Жирекенское месторождение молибдена (штокверк среди брекчированных гранитов) разрабатывается с перерывами с 1986 г. Доказанные запасы составляют 10.6 млн т руды. В рассматриваемой группировке широко распространены промышленные месторождения флюорита, образующие ряд рудных узлов. Так, месторождение Калангуй, известное с 1918 г., в прошлом веке было крупнейшим в регионе. Из главного рудного тела и отходящих от него рудных жил было извлечено 1.7 млн т флюорита. На Усуглинском месторождении флюорита, изучавшемся автором в девяностые годы прошлого столетия, жило- и линзообразные тела со столбообразными участками формировались в трех зонах дробления северо-западного простирания в борту рифтогенной впадины юрско-мелового возраста. Наиболее богатое оруденение приурочено к участкам зон на пересечении ими блоков осадочно-метаморфогенных пород среди гранитоидов.

Значительными остаются перспективы ураноносности группировки, что определяется наличием двух рудных узлов: Оловского (месторождения Оловское, Зюльзинское и др.) и Могочинского (месторождения Часовое, Королевское и др.). На Оловском месторождении тела гидротермальных руд пластообразной формы залегают в осадочно-вулканогенной толще одноименной впадины и сложены тонковкрапленными и дисперсными минеральными ассоциациями. Богатые урановые руды месторождений Могочинского узла имеют жилообразную, линзообразную, гнездовую форму, не выдержаны по простиранию и падению. Месторождения урана этой группировки находятся в резерве.

Даурско-Агинская группировка занимает юго-западную часть пояса. Ее территория в значительной мере характеризуется доступностью для наземного транспорта (за исключением крайних западных районов) и относительно хорошо развитой инфраструктурой. Месторождения золота, олова, вольфрама, тантала разрабатывались или разрабатываются в настоящее время. Наиболее значимыми являются узлы Орловско-Спокойнинский (редкоземельные металлы, вольфрам), Уронайский медно-золото-вольфрамо-висмутовый, Любавинско-Хапчерангинский (золото, олово), Акуинский (уран), Барун-Шивеинский (вольфрам, сурьма), Шероловогорский (олово, полиметаллы). Орловско-Спокойнинский узел включает Спокойнинское месторождение вольфрама, Орловское месторождение тантала и ряд более мелких объектов, локализующихся в границах Хангилай-Шилинского массива гранитоидов, выходящего на поверхность в виде трех отдельных куполов. Рудные тела этого альбитит-грейзенового месторождения залегают в породах кровли массива (пластообразные залежи) и в куполе альбититовых гранитов (штокверк). Любавинское месторождение золота и Хапчерангинское олова находятся на юге группировки. Первое локализуется в широтной зоне дробления и представлено кварцевыми жилами и штокверками (Евграфовский) среди юрских гранитоидов и песчано-сланцевых толщ перми. Разработка его с перерывами проводилась с 1891 г. В 2011 г. после доразведки ресурсы составили около 15 т золота. Оловорудное месторождение Хапчеранга разрабатывалось с 1934 г. до выработки запасов в 1962 г., с 1952 г. до начала 70-х гг. эксплуатировались полиметаллические руды месторождения с получением свинца и цинка. Добыча на ряде месторождений редких и цветных металлов этой группировки была законсервирована в связи с покупкой некоторых видов сырья за границей, например вольфрама в Китае, или в связи с нерентабельностью разработки. В настоящее время начинаются реконструкция 
ряда горных предприятий и повторная эксплуатация некоторых месторождений.

\section{5. Керуленско-Приаргунский пояс}

Занимает крайнюю юго-восточную часть территории, продолжаясь в северные районы Восточной Монголии и Китая. Он контролируется одноименной системой разломов в пределах Аргунского супертеррейна. Здесь среди протерозойских метаморфических, осадочно-метаморфогенных пород широко развиты мезозойские вулкано-тектонические центры и приразломные впадины юрско-мелового возраста, выполненные терригенными, часто угленосными отложениями и базальтами. Эти центры контролируются узлами пересечения протяженных разломов северо-восточного простирания с более короткими разноориентированными разрывными нарушениями. Богатством и разнообразием месторождений полезных ископаемых отличается выделяемая здесь территориальная группировка.

Приаргунская группировка прослеживается в северо-западном направлении вдоль р. Аргунь. Минерагенический фон этой площади определяется промышленными концентрациями полиметаллов (свинец, цинк, серебро), урана, флюорита, кроме того, имеются месторождения золота, угля, железа, которые концентрируются в пределах нескольких рудных узлов. Прежде всего, необходимо отметить, что здесь находится один из крупнейших в стране Стрельцовский урановорудный узел (Урулюнгуйский урановорудный район), включающий 20 промышленных месторождений урана, локализующихся в пределах Тулукуевской палеокальдеры, выполненной юрско-меловыми вулканитами (риолиты, дациты, андезиты, их туфы, базальты), которые формировались в течение трех вулканических циклов [Laverov, 1995; Samovich et al., 2012]. Рудные тела разнообразны по форме (жилы простые и сложные, жильные зоны, линейные штокверки, пластообразные залежи, залежи сложной формы), локализуются на разных уровнях разреза и в породах фундамента. Эксплуатация проводится Приаргунским горно-химическим комбинатом, построен г. Краснокаменск.

На территории Приаргунья еще в XVIII-XIX вв. эксплуатировались месторождения полиметаллов (свинец, цинк, серебро, а также золото, кадмий, висмут), образующие несколько рудных узлов. Это такие месторождения, как Екатерино-Благодатское, Кадаинское, Воздвиженское, Кличкинское, Савинское и др. Месторождения Кличкинского узла, известные с 1759 г., эксплуатировались с 80-х гг. XVIII в. В 1995 г. эксплуатация была практически прекращена из-за нерентабельности Нерчинского полиметаллического комбината и запасы были переведены в нераспределенный фонд. В 2008 г. после разведки и начала добычи на месторождении Нойон-Тологой был определен новый тип колчеданно-полиметаллические месторождения с золотом. К данному типу также отнесено Ново-Широкинское месторождение Пришилкинской группировки. Большинство месторождений полиметаллов средние и мелкие, однако общие запасы их значительны (около 90 \% запасов полиметаллических руд Забайкальского края). В пределах группировки локализуются промышленные месторождения флюорита, в том числе наиболее ценных металлургических сортов (Бугутуро-Абагайтуйский, Уртуйский, Тулукуевский, Урулюнгуйский рудные узлы). Наиболее крупным является Уртуйское месторождение, которое (вместе с Абагайтуйским) локализуется в зоне сброса среди андезитов и кварцевых порфиров и представлено серией жилообразных тел, в том числе девятью промышленными с разведанными запасами 2.31 млн т.

\section{6. ЗАКЛЮЧЕНИЕ}

1. Месторождения полезных ископаемых рассматриваемого региона формировались в различные минерагенические эпохи начиная с палеопротерозоя и связаны с разнообразными геологическими процессами. На Сибирской платформе образование эндогенных месторождений происходило в период формирования ее фундамента, выходящего на поверхность в пределах Алданского, Анабарского, Шарыжалгайского щитов. Активные эндогенные и экзогенные рудообразующие процессы имели место в течение формирования геологических комплексов чехла в периоды осадконакопления, вулканической и плутонической деятельности. В Центрально-Азиатской складчатой области в течение длительной геологической истории и смены разнообразных геодинамических обстановок формирование месторождений полезных ископаемых происходило на конвергентных и дивергентных границах плит, в субдукционных и коллизионных обстановках, но особенно продуктивной была мезозойская минерагеническая эпоха, связанная с проявлением плюмтектонических процессов и внутриплитного орогенеза (южная и центральная части региона). Многообразная тектоническая и магматическая деятельность предопределила сложность структурной обстановки рудообразования, особенно в пределах Центрально-Азиатской складчатой области, и весьма разнообразные структурно-морфологические особенности месторождений полезных ископаемых, что показано при характеристике рудных и нерудных объектов в территориальных группировках. На многих месторождениях, даже претерпевших эксплуатацию, оставались неизученными глубокие горизонты и фланги, что определило необходимость проведения повторной разведки и эксплуатации.

2. Большинство месторождений полезных ископаемых региона находятся в пределах двенадцати территориальных группировок минерального сырья, входящих в состав минерагенических поясов окраинно-кратонной, коллизионно-аккрекционной, внутриплитной плюмтектонической природы. При этом практически все группировки содержат крупные, а часто уникальные месторождения полезных ископаемых. Некоторые группировки находятся в зонах влияния Транссибирской или Байкало-Амурской железнодорожных 
магистралей. Однако географо-экономические условия группировок, особенно в северной половине региона, являются весьма сложными и характеризуются слабо развитой инфраструктурой, что не позволяет говорить об их освоении в ближайшем будущем. Не решенными в этих районах являются проблемы энергоснабжения, транспортных коммуникаций и др. К наиболее благоприятным для освоения относятся месторождения группировок южной части региона: Присаянской, Еравнинской, Даурско-Агинской, Пришилкинской, Приаргунской, Селенгинской, а также частично Мамско-Бодайбинской и Чаро-Муйской на севере. В их пределах находятся старые горнорудные районы России, освоение некоторых из них происходило в XVII-XIX вв. Конечно, будут интенсивно разрабатываться месторождения районов нефтегазодобычи Непской группировки, что обусловлено функционированием нефтепровода ВСТО.

3. Необходимо отметить, что за многие десятилетия добычи полезных ископаемых в старых горнорудных районах скопились значительные объемы техногенного сырья, которое практически не используется и является сырьем будущего. Например, на полиметаллических рудниках Пришилкинской и Приаргунской группировок (Кадая, Кличка, Акатуй, Благодатка) в хвостохранилищах обогатительных фабрик содержится более 30 тыс. т свинца, 139 тыс. т серебра, более 80 тыс. т цинка, около 1.5 т золота. В отходах Балейской золотоизвлекательной фабрики запасы золота составляют 9755 кг, хотя месторождение было отработано подземными выработками, затем повторно - открытым способом. Разработана технология обогащения и получения металлов. Та же ситуация на рудниках Даурско-Агинской, Селенгинской и других группировок.

4. Многие годы обсуждается проблема так называемых малых месторождений в экономически освоенных районах, разработка которых возможна при введении в производство разведочно-эксплуатационных предприятий с применением малых обогатительных установок в течение 5-8 лет. Как правило, это незначительные по запасам, но богатые по содержанию полезных компонентов объекты. При этом не требуется создание социально-производственной инфраструктуры и может быть использовано техногенное сырье. Опыт работы старательских артелей показывает рентабельность таких предприятий и возможность обходиться без федеральных инвестиций. Возобновление отработки ряда месторождений возможно на основе применения подвижных обогатительных комплексов и совершенствования технологии добычных работ. В Восточной Сибири наиболее вероятна разработка малых месторождений свинца, цинка, олова, вольфрама, тантала, ниобия, молибдена, золота, камнесамоцветного и другого сырья.

\section{7. КОНФЛИКТ ИНТЕРЕСОВ}

Автор заявляет об отсутствии конфликта интересов.

\section{8. ЛИТЕРАТУРА / REFERENCES}

Belichenko V.G., Sklyarov E.V., Dobretsov N.L., Tomurtogo 0., 1994. Geodynamic Map of the Paleo-Asian Ocean. Eastern segment. Russian Geology and Geophysics 35 (78), 29-41 (in Russian) [Беличенко В.Г., Скляров Е.В., Добрецов Н.Л., Томуртогоо О. Геодинамическая карта Палеоазиатского океана. Восточный сегмент // Геология и геофизика. 1994. Т. 35. № 7-8. С. 29-41].

Chechetkin V.S., Kharitonov Yu.F., Chaban Yu.F., 2011. Mineral Resources of the Transbaikalia Territory. Prospects for Exploration and Development. Mining Journal 3, 18-23 (in Russian) [Чечёткин В.С., Харитонов Ю.Ф., Чабан Ю.Ф. Минерально-сырьевые ресурсы Забайкальского края. Перспективы освоения и развития // Горный журнал. 2011. № 3. C. 18-23].

Chechetkin V.S., Trubachev A.I., 2013. Mineral Resources of the Transbaikalia Territory. Transbaikalia State University, Chita, 231 p. (in Russian) [Чечёткин В.С., Трубачёв А.И. Минеральные ресурсы Забайкальского края. Чита: ЗабГУ, 2013. 231 c.].

Dobretsov N.L., Kirdyashkin A.G., Kirdyashkin A.A., 2001. Deep Geodynamics. GEO, Novosibirsk, 409 p. (in Russian) [Добрецов Н.Л., Кирдяшкин А.Г., Кирдяшкин А.А. Глубинная геодинамика. Новосибирск: Гео, 2001. 409 с.].

General Information on the Mineral Resources of the Republic of Buryatia, 2015 (in Russian) [Общая информация о минерально-сырьевых ресурсах Республики Бурятия, 2015]. Available from: https://gordburyatia.ru/priroda/ 24-obschaya-informaciya-o-mineralno-syrevyh-resursahrespubliki-buryatiya.html (Last Accessed 01.03.21).

Gordienko I.V., 2014. Metallogeny of Various Geodynamic Settings of the Mongolia-Transbaikalia Region. Geology of Mineral Resources of Siberia S3-1, 7-13 (in Russian) [Гордиенко И.В. Металлогения различных геодинамических обстановок Монголо-Забайкальского региона // Геология минерально-сырьевых ресурсов Сибири. 2014. № S3-1. C. 7-13].

Gordienko I.V., Gorokhovsky D.V., Lantseva V.S., Badmatsirenova R.A., 2017. Dzhida Ore Region: Structure, Metallogeny, Geodynamics, and Development Prospects. Bulletin of the Siberian Branch of the Earth Sciences Section of the Russian Academy of Natural Sciences. Geology, Exploration and Development of Mineral Deposits 40 (1), 9-31 (in Russian) [Гордиенко И.В., Гороховский Д.В., Ланцева В.С., Бадмациренова Р.А. Джидинский рудный район: строение, металлогения, геодинамика, перспективы развития // Известия Сибирского отделения секции наук о Земле РАЕН. Геология, разведка и разработка месторождений полезных ископаемых. 2017. Т. 40. № 1. C. 9-31].

Gordienko I.V., Nefediev M.A., Platov V.S., 2013. Structure, Mineral Types of Ore Deposits and Development Prospects of the Eravna Ore Region of Transbaikalia. Bulletin of the Siberian Branch of the Earth Sciences Section of the Russian Academy of Natural Sciences 1 (42), 7-21 (in Russian) [Гордиенко И.В., Нефедьев М.А., Платов В.С. Строение, минеральные типы рудных месторождений и перспективы освоения Еравнинского рудного района 
Забайкалья // Известия Сибирского отделения секции наук о Земле РАЕН. 2013. № 1 (42). С. 7-21].

Konstantinov M.M. (Ed.), 2010. Gold Deposits of Russia. Akvarel, Moscow, 365 p. (in Russian) [Золоторудные месторождения России / Ред. М.М. Константинов. М.: Акварель, 2010. 365 с.].

Korol'kov A.T., 2007. Geodynamics of Gold Ore Regions of the Southern East Siberia. ISU Publishing House, Irkutsk, 251 р. (in Russian) [Корольков А.Т. Геодинамика золоторудных районов юга Восточной Сибири. Иркутск: Издво ИГУ, 2007. 251 с.].

Laverov N.P. (Ed.), 1995. Deposits of Transbaikalia. Geoinformmark, 244 p. (in Russian) [Месторождения Забайкалья / Ред. Н.П. Лаверов. М.: Геоинформмарк, 1995. 244 с.].

Mineral Resource Base of the Irkutsk Region, 2010 (in Russian) [Минерально-сырьевая база Иркутской области, 2010]. Available from: https://www.vnedra.ru/o-re gionah/mineralno-syrevaya-baza-irkutskoj-o-75/ (Last Accessed 05.03.21).

Mineral Resource Complex of Transbaikalia: Today and, Probably, Tomorrow, 2008 (in Russian) [Минерально-сырьевой комплекс Забайкалья: сегодня и, возможно, завтра. 2008. Available from: https://studwood.ru/1282634/geo grafiya/mineralno_syrevoy_kompleks_zabaykalya_voz mozhno_zavtra (Last Accessed 09.03.21).

Nokleberg W.J. (Ed.), 2010. Metallogenesis and Tectonics of Northeast Asia. USGS Professional Paper 1765. U.S. Geological Survey, Reston, Virginia, 624 p.

Obolensky A.A., Kuzmin M.I., Rodionov S.M., Nokleberg U.J., Berzin N.A., Distanov E.G., Sotnikov V.I., Seminsky Zh.V. et al., 2006. Terrain Metallogeny of Central and North-East Asia (International Project Results). In: Top Problems of Ore Formation and Metallogeny. Abstracts of Reports of the International Meeting Dedicated to the 100th Anniversary of the Birth of Academician V.A. Kuznetsov (April 10-12, 2006). GEO, Novosibirsk, 168-169 (in Russian) [Оболенский A.A., Кузьмин М.И., Родионов С.М., Ноклеберг У.Дж., Берзин Н.А., Дистанов Э.Г., Сотников В.И., Семинский Ж.В. и др. Террейновая металлогения Центральной и Северо-Восточной Азии (результаты работ по международному проекту) // Актуальные проблемы рудообразования и металлогении: Тезисы докладов международного совещания, посвященного 100-летию со дня рождения академика В.А. Кузнецова (10-12 апреля 2006 г.). Новосибирск: Гео, 2006. C. 168-169].

Parfenov L.M. (Ed.), 1994. Geodynamic Map of Yakutia and Adjacent Territories, Scale of 1:1500000. Main Office of Geodesy and Cartography, Yakutsk, 12 p. (in Russian) [Геодинамическая карта Якутии и сопредельных территорий масштаба 1:1500000 / Ред. Л.М. Парфенов. Якутск: ГУГК, 1994. 12 л.].

Parfenov L.M., Berzin N.A., Khanchuk A.I., Badarch G., Belichenko V.G., Bulgatov A.N., Dril S.I., Kirillova G.L. et al., 2003. Model of the Formation of Orogenic Belts in Central and North-East Asia. Pacific Geology 22 (6), 7-41 (in Russian) [Парфенов Л.М., Берзин Н.А., Ханчук А.И., Бадарч Г., Беличенко В.Г., Булгатов А.Н., Дриль С.И., Кириллова Г.Л. и др. Модель формирования орогенных поясов Центральной и Северо-Восточной Азии // Тихоокеанская геология. 2003. T. 22. № 6. C. 7-41].

Parfenov L.V., Bulgatov A.N., Gordienko I.V., 1995. Terranes and Accretionary History of the Transbaical Orogenic Belts. International Geology Review 37 (8), 736-751. https:// doi.org/10.1080/00206819509465425.

Parfenov L.M., Kuzmin M.I. (Eds), 2001. Tectonics, Geodynamics and Metallogeny of the Sakha Republic (Yakutia). MAIK Nauka/Interperiodica, Moscow, 571 p. (in Russian) [Тектоника, геодинамика и металлогения территории Республики Саха (Якутия) / Ред. Л.М. Парфенов, М.И. Кузьмин. М.: МАИК «Наука/Интерпериодика», 2001. 571 с.].

Plushchev E.V. (Ed.), 2001. Ore Nodes of Russia. VSEGEI Publishing House, Saint Petersburg, 416 p. (in Russian) [Рудные узлы России / Ред. Е.В. Плющев. СПб.: Изд-во ВСЕГЕИ, 2001. 416 c.].

Samovich D.A., Tsaruk I.I., Kokarev A.A. et al., 2012. Mineral Resource Base of Uranium in East Siberia. Glazkovo Printing House, Irkutsk, 164 p. (in Russian) [Самович Д.А., Царук И.И., Кокарев А.А. и др. Минерально-сырьевая база урана Восточной Сибири. Иркутск: Глазковская типография, 2012. 164 с.].

Seminsky Zh.V., 2004. Metallogenic Zoning Based on Plum Tectonics and Deep-Seated Structure of the Earth Crust, Exemplified by Trans-Baikal Area. In: A.I. Khanchuk, G.A. Gonevchuk, A.N. Mitrokhin, L.F. Simanenko, N.J. Cook, R. Seltmann (Eds), Metallogeny of the Pacific Northwest (Russian Far East): Tectonics, Magmatism and Metallogeny of Active Continental Margins. Proceedings of the Interim IAGOD Conference (September 1-20, 2004). Dal'nauka, Vladivostok, p. 152-153.

Seminsky Zh.V., 2006. Metallogenic Belts of the Southern East Siberia. Bulletin of the Siberian Branch of the Earth Sciences Section of the Russian Academy of Natural Sciences. Geology, Prospecting and Exploration of Ore Deposits 3 (29), 5-15 (in Russian) [Семинский Ж.В. Металлогенические пояса Юго-Восточной Сибири // Известия Сибирского отделения секции наук о Земле РАЕН. Геология, поиски и разведка рудных месторождений. 2006. № 3 (29). С. 5-15].

Seminsky Zh.V., 2015. Endogenous Ore Systems of the Southern East Siberia in the Inversion Layer of the Earth's Crust. Bulletin of the Siberian Branch of the Earth Sciences Section of the Russian Academy of Natural Sciences. Geology, Exploration and Development of Mineral Deposits 2 (51), 5-18 (in Russian) [Семинский Ж.В. Эндогенно-рудные системы Юго-Восточной Сибири в инверсионном слое земной коры // Известия Сибирского отделения секции наук о Земле РАЕН. Геология, разведка и разработка месторождений полезных ископаемых. 2015. № 2 (51). С. 5-18].

Seminsky Zh.V., 2017. Ore Belts of the Baikal-Transbaikalia Region. Bulletin of the Siberian Branch of the Earth Sciences Section of the Russian Academy of Natural Sciences. Geology, Exploration and Development of Mineral Deposits 40 (3), 20-34 (in Russian) [Семинский Ж.В. Рудные пояса Байкало-Забайкальского региона // Известия Сибирского отделения секции наук о Земле РАЕН. Геология, разведка и разработка месторождений полезных ископаемых. 2017. Т. 40. № 3. С. 20-34]. 
ПРИЛОЖЕНИЕ 1 / APPENDIX 1

Таблица 1. Территориальные группировки минеральных ресурсов Юго-Восточной Сибири

Table 1. Clusters of mineral deposits of the Southern East Siberia

\begin{tabular}{|c|c|c|}
\hline $\begin{array}{l}\text { Название, } \\
\text { № на рис. } 1\end{array}$ & $\begin{array}{c}\text { Администра- } \\
\text { тивное } \\
\text { положение }\end{array}$ & $\begin{array}{c}\text { Ведущие геологические формации } \\
\text { и комплексы; геодинамические } \\
\text { и тектонические элементы }\end{array}$ \\
\hline $\begin{array}{l}\text { Ангаро- } \\
\text { Илимская } \\
1\end{array}$ & $\begin{array}{l}\text { Иркутская } \\
\text { область, } \\
\text { частично } \\
\text { Красноярский } \\
\text { край }\end{array}$ & $\begin{array}{l}\text { Терригенно-карбонатные } \\
\text { туфопирокластические, интрузивные трап- } \\
\text { повые. Приангарская впадина Тунгусской } \\
\text { синеклизы, диатремы трапповой формации }\end{array}$ \\
\hline $\begin{array}{l}\text { Непская } \\
2\end{array}$ & $\begin{array}{l}\text { Иркутская } \\
\text { область }\end{array}$ & $\begin{array}{l}\text { Песчано-алевритовые, доломитовые с } \\
\text { соленосными горизонтами и пластовыми } \\
\text { интрузиями долеритов. Непский свод Непско- } \\
\text { Ботуобинской антеклизы }\end{array}$ \\
\hline
\end{tabular}

$\begin{array}{lll}\text { Присаянская } & & \text { Пироксен-амфиболовые гнейсы, сланцы, } \\ \text { (Черемхов- } & \text { Иркутская } & \text { мраморы; терригенно-карбонатные, } \\ \text { ская) } & \text { обленосные, угленосные. Черемховская } \\ 3 & \text { впадина Присаянского краевого прогиба, } \\ & \text { частично Шарыжалгайский метаморфический } \\ & \text { террейн (щит платформы) }\end{array}$

\begin{tabular}{lll}
\hline & Республика & Терригенно-карбонатная метаморфизованных \\
Северо- & Бурятия, & комплексов; вулканогенно-зеленокаменная, \\
Байкальская & частично & вулканогенная, габбро-перидотитовая. В \\
4 & Иркутская & юго-западной части композитного Байкало- \\
& область & Муйского супертеррейна
\end{tabular}

\begin{tabular}{|c|c|c|}
\hline $\begin{array}{l}\text { Мамско- } \\
\text { Бодайбинская } \\
\text { (Мамская } \\
\text { подзона) } \\
5\end{array}$ & $\begin{array}{l}\text { Иркутская } \\
\text { область }\end{array}$ & $\begin{array}{l}\text { Биотитовые, кианит-гранат-биотитовые } \\
\text { гнейсы, известняки. Северная часть } \\
\text { Байкало-Муйского супертеррейна; Мамско- } \\
\text { Бодайбинский сложнодислоцированный } \\
\text { прогиб }\end{array}$ \\
\hline $\begin{array}{l}\text { Мамско- } \\
\text { Бодайбинская } \\
\text { (Бодайбин- } \\
\text { ская подзона) } \\
5\end{array}$ & $\begin{array}{l}\text { Иркутская } \\
\text { область }\end{array}$ & $\begin{array}{l}\text { Ритмичная углеродистая (черносланцевая) кар- } \\
\text { бонатно-терригенного состава. Северная часть } \\
\text { Байкало-Муйского террейна; Мамско-Бодай- } \\
\text { бинский сложнодислоцированный прогиб }\end{array}$ \\
\hline
\end{tabular}

$\begin{array}{ll}\text { Селенгинская } & \\ \text { (Джидинская) } & \text { Республика } \\ 6 & \text { Бурятия }\end{array}$

Габбро-диорит-плагиогранитная, базальтовая, риолит-андезитовая, терригенно-карбонатная, гранитоидов. Хамар-Дабанский, частично Джидинский островодужные террейны; в мезозое - внутриплитный ороген
Главные полезные ископаемые и месторождения; рудные формации; формы рудных тел для наиболее значительных объектов

Железо (Коршуновское, Нерюндинское, Рудногорское и др. - штокверково-жильные тела в диатремах). Соли

Нефть, газ (Непско-Ботуобинский нефтегазоносный район - Верхнечонское, Ковыктинское, Чаяндинское, Талаканское и др. - нефтегазоносные залежи в карбонатных и терригенных породах). Калийные соли (Непская группа). Железо

Уголь (Иркутский бассейн, 20 месторождений Черемховское, Вознесенское и др. - многозалежные пластовые, от 2 до 20 пластов)

Соли (Усольское, Тыретское и др.).

Магнезит, тальк (Савинское, Онотское). Тантал, ниобий (Белозиминское - карбонатитовые штоко- и жилообразные тела). Титан (Тулунское, Нижнеудинское ильменитсодержащие песчаники, древние россыпи)

Свинец, цинк: колчеданно-полиметаллическая (Холоднинское, Галенитовое, Иокское и др. стратиформные пласто- и линзообразные залежи), свинцово-цинково-флюоритовая формации. Никель (Чайское - вытянутые тела сульфидно-медноникелевых руд в ядре массива пироксенитов, габбро)

Мусковит (Витимское, Колотовка, Луговка и др. согласные, секущие тела пегматитов (более 2300 жил) в пределах пояса северо-восточного простирания протяженностью около 200 км

Золото (Сухой Лог, Первенец, Вернинское и др. - залежи прожилково-вкрапленных руд, жилы золото-кварцевой минерализации), россыпи

Молибден-вольфрамовая ассоциация

(Джидинское рудное поле: месторождения Первомайское, Инкурское, Холтосонское - штокверки, жилы и др. тела, Булуктайское).

Флюорит (Норанское). Золото, полиметаллы. Уголь (Гусиноозерское)

Свинец, цинк, железо: колчеданно-свинцово-цинковая и сидеритовая (Озерное, Назаровское, Ульзутуйское пластовые, пластообразные, линзовидные, лентообразные, жильные тела на разных стратиграфических уровнях).

Флюорит (Эгитинское - прожилково-вкрапленные, жильные, линзовидные тела) нический блок карбонатных пород в пределах батолита гранитоидов

Терригенно-карбонатная, кварцитоРеспублики черносланцевая алеврито-песчаниковая Чаро-Муйская Бурятия, (Чарская под- Якутия, зона) частично 8 Иркутская область меденосная, гранитоидов, габбро-перидотитовая, габбро-анортозитовая. Восточная часть Байкало-Муйского супертеррейна, Муйский метаморфический террейн; зона сочленения антиклинальных и синклинальных структур кратона и Алдано-Станового супертеррейна

Амфиболитовая, гнейсовая, кристаллических сланцев, песчано-сланцевая, вулканогеннотерригенная, гранитоидов, габбро-анортозитовая; ультрабазитовая, габбро-плагиогранитная. Восточная часть Байкало-Муйского супертеррейна, Муйский террейн; архейскопротерозойская глыба со сшивающими и перекрывающими комплексами, нарушенная разломами
Медь (Удоканское - пластовые многоуровневые залежи, Красное, Бурполинское и др.), медно-титано-ванадиевые руды (Чинейское расслоенный плутон).

Редкие и редкоземельные элементы - тантал, ниобий, редкие земли (Катугинское). Золото

Золото - Келяно-Ирокиндинская и др. рудные зоны (Ирокинда, Кедровское, Витимское и др. - более 100 жил и жильных зон малосульфидно-кварцевой, золотокварцевой формаций), россыпи.

Хризотил-асбест (Молодежное в гипербазитах). Олово (Моховое). Нефрит (Голюмбинское и др.) 
Таблица 1. (продолжение)

Table 1. (continued)

\begin{tabular}{|c|c|c|c|}
\hline $\begin{array}{l}\text { Название, } \\
\text { № на рис. } 1\end{array}$ & $\begin{array}{l}\text { Администра- } \\
\text { тивное } \\
\text { положение }\end{array}$ & $\begin{array}{c}\text { Ведущие геологические формации } \\
\text { и комплексы; геодинамические } \\
\text { и тектонические элементы }\end{array}$ & $\begin{array}{c}\text { Главные полезные ископаемые и месторождения; } \\
\text { рудные формации; формы рудных тел - } \\
\text { для наиболее значительных объектов }\end{array}$ \\
\hline $\begin{array}{l}\text { Чикойская } \\
9\end{array}$ & $\begin{array}{l}\text { Забайкальский } \\
\text { край }\end{array}$ & $\begin{array}{l}\text { Биотитовых, двуслюдяных гнейсов, сланцев, } \\
\text { терригенные (филлиты, песчаники), } \\
\text { интрузивные гранитоидные, юго-западная } \\
\text { часть Монголо-Охотского композитного } \\
\text { супертеррейна, активизированная в мезозое } \\
\text { на плюмтектоническом этапе }\end{array}$ & $\begin{array}{l}\text { Вольфрам, олово } \\
\text { (Шумиловское, Молодежное, Асаканское, Мензинское } \\
\text { и др. - штокверки, жилы). } \\
\text { Золото }\end{array}$ \\
\hline $\begin{array}{l}\text { Даурско-Агин- } \\
\text { ская } \\
10\end{array}$ & $\begin{array}{l}\text { Забайкальский } \\
\text { край }\end{array}$ & $\begin{array}{l}\text { Песчано-сланцевая (флиш), терригенно- } \\
\text { карбонатная, габбро-диорит-гранодиоритовая, } \\
\text { лейкогранитовая, дацит-андезитовая. } \\
\text { Агинский и Даурский террейны Монголо- } \\
\text { Охотского супертеррейна, активизированные } \\
\text { в мезозое внутриплитным орогенезом }\end{array}$ & $\begin{array}{l}\text { Золото (Любавинское, Мало-Федоровское и др. - } \\
\text { жилы, штокверки в зоне разломов, Ара-Иля - трубка с } \\
\text { вкрапленной минерализацией). } \\
\text { Олово, вольфрам (Хапчерангинское - жилы). } \\
\text { Тантал, вольфрам, олово (Орловско-Спокойнинское - } \\
\text { жилы, штокверки, связанные с альбититами и } \\
\text { грейзенами) }\end{array}$ \\
\hline $\begin{array}{l}\text { Пришилкин- } \\
\text { ская } \\
11\end{array}$ & $\begin{array}{l}\text { Забайкальский } \\
\text { край }\end{array}$ & $\begin{array}{l}\text { Нижний структурный этаж-гранит- } \\
\text { гранодиоритовые, гранито-гнейсовые с } \\
\text { блоками сланцев, гнейсов и терригенно- } \\
\text { карбонатных пород; верхний этаж - андезит- } \\
\text { базальтовые, гранодиоритовые, сиенитовые, } \\
\text { лейкогранитовые. Шилкинский и Яблоновый } \\
\text { террейны, на сочленении Станового и } \\
\text { Аргунского супертеррейнов, активизирован- } \\
\text { ные в мезозое внутриплитным орогенезом }\end{array}$ & $\begin{array}{l}\text { Золото (Дарасунское, Карийское, Уконик и др. - жилы, } \\
\text { зоны; Балейское, Тасеевское - полого- и крутопадаю- } \\
\text { щие жилы), Ново-Широкинское - зоны разломов с } \\
\text { жильными рудными телами. } \\
\text { Молибден (Жирекен, Давенда, Бугдая и др. - жилы, } \\
\text { штокверки). } \\
\text { Уран (Оловское, Часовое и др. - линзы, гнездообразные } \\
\text { залежи, пластообразные тела). } \\
\text { Тантал, вольфрам (Этыка и др.). } \\
\text { Флюорит (Усуглинское, Улунтуйское, Калангуй и др. - } \\
\text { жилы, зоны) }\end{array}$ \\
\hline $\begin{array}{l}\text { Приаргунская } \\
12\end{array}$ & $\begin{array}{l}\text { Забайкальский } \\
\text { край }\end{array}$ & $\begin{array}{l}\text { Нижний структурный этаж - гранито- } \\
\text { гнейсовые, гранитоидные, терригенно-карбо- } \\
\text { натные комплексы; верхний структурный } \\
\text { этаж (внутриплитный этап): базальтовые, } \\
\text { базальт-андезит-риолитовые), плутонические } \\
\text { (гранодиоритовые, граносиенитовые, лейко- } \\
\text { гранитовые). Аргунский, частично Шилкинский } \\
\text { террейны, в мезозое - внутриплитный ороген }\end{array}$ & $\begin{array}{l}\text { Полиметаллы (Савинское, Кадаинское, Екатерино- } \\
\text { Благодатское и др. - жилы, штокверки, гнезда, столбо- } \\
\text { образные залежи). } \\
\text { Уран (Стрельцовская группа и др. - жилы, рудные зоны, } \\
\text { штокверки, залежи неправильной формы). } \\
\text { Флюорит (Гарсонуевское, Шахматное и др.). } \\
\text { Золото (Нойон-Тологой) }\end{array}$ \\
\hline
\end{tabular}

